\title{
DETERMINATION OF PLASMINOGEN/PLASMIN SYSTEM COMPONENTS AND INDICATORS OF LIPOPROTEINS OXIDATIVE MODIFICATION UNDER ARTERIAL HYPERTENSION
}

\author{
O. I. YUSOVA ${ }^{1}$, O. V. SAVCHUK ${ }^{1}$, T. V. GRINENKO ${ }^{1}$, O. B. KUCHMENKO ${ }^{2}$, \\ L. S. MHITARYAN ${ }^{2}$, O. H. KUPCHINS'KA', I. N. YEVSTRATOVA', \\ O. O. MATOVA' ${ }^{2}$ N. M. VASILINCHUK ${ }^{2}$, T. F. DROBOT'KO' \\ ${ }^{1}$ Palladin Institute of Biochemistry, National Academy of Sciences of Ukraine, Kyiv; \\ e-mail: yusova07@gmail.com; \\ ${ }^{2}$ SI NSC "Strazhesko Institute of Cardiology", National Academy \\ of Medical Sciences of Ukraine, Kyiv
}

The present study was investigated of levels of oxidative modification of lipoproteins and content of plasminogen/plasmin system components - tissue-type plasminogen activator (t-PA) and plasminogen activators inhibitor-1 (PAI-1), in patients with stage II arterial hypertension (AHT) and resistant form of AHT. It was established that t-PA level in blood plasma of the patients is 2 times lower under stage II hypertension than normal and 2.5 times lower under resistant AHT. The inhibitor activity is 1.5 and 2 times higher consequently. It is concluded that patients with AHT have a decreased fibrinolytic potential, which can cause thrombotic states. Our evaluation showed a significant accumulation of products of lipid and protein oxidation, decrease of activity of antioxidant enzymes and changes of the activity of high density-lipoproteins-associated enzymes (decrease of paraoxonase-1 activity, increase of myeloperoxidase activity). Oxidized lipoproteins, $t$-PA and PAI-1 can be used as prognostic markers of development of complications and for evaluating the efficacy of therapy in patients with arterial hypertension.

Ke ywords: oxidized lipoproteins, tissue-type plasminogen activator, plasminogen activators inhibitor-1, arterial hypertension (AHT).

A rterial hypertension (AHT) takes the first place among the blood circulation system diseases and is an independent risk factor of development of cardiovascular complications that is myocardial infarction and ischemic insult. The resistant form of AHT (when the systolic pressure is higher than $140 \mathrm{~mm}$ of mercury column, diastolic pressure is higher than $90 \mathrm{~mm}$ of mercury column provided that the patient keeps to recommendations as to the mode of life and the use of antihypertensive therapy that includes the taking of at least three drugs of various classes, one of which is a diuretic, that increases essentially the risk of hypertensive injury of organs-targets, probability of appearance of cardio-vascular complications. The patients with resistant AHT account from 3 to 30\% among all the patients with AHT. The life of patients with AHT, especially with its resistant proceeding and dama- ge of organs-targets, especially decreases. One of the basic links of AHT pathogenesis, including its resistant form, is the development of microangiopathias, which appear as based on the inflammation process, oxidative stress, disturbance of lipid metabolism and hemostasis system as well as development of endothelium dysfunction [1, 2]. Investigation of the recent years have shown that low and high density lipoproteins (LDL and HDL) play a complex role in the functioning of the cardiovascular system in norm and with pathology, manifesting antiinflammatory, antioxidant, immunomodulating, antiapoptotic and antithrombotic effects. These effects are connected with lipid and protein molecules associated with them. The well-known factor is the relation between the content and structure of lipoproteins and activity of fibrinolytic system. It has been shown that HDL favor plasmin generation and thus the increase

(C) 2018 Yusova O. I. et al. This is an open-access article distributed under the terms of the Creative Commons Attribution License, which permits unrestricted use, distribution, and reproduction in any medium, provided the original author and source are credited. 
of fibrinolytic potential. While the oxidated form of HDL, revealed in atherosclerotic plaques, intensifies the expression of plasminogen activators inhibitor-1 (PAI-1) in endotheliocytes and thus decreases fibrinolysis and stabilizes the clot [3].

The most important components of fibrinilytic system, which play a key role in regulation of fibrinolysis process, include t-PA (EC 3.4.21.68.) and PAI-1. t-PA is a physiological activator of plasminogen - serine proteinase, which is synthesized by endotheliocytes and released into the blood circulation system in the active form. Plasminogen activation by $\mathrm{t}$-PA proceeds at the surface of fibrin, i.e. the formation of a fibrin clot initiates the process of activation of the fibrinolytic system and appearance of plasminogen activity [4]. Being in the state connected with fibrin, plasmin, which has been formed, and t-PA are defended from inactivation with inhibitors $-\alpha 2$ antiplasmin and PAI-1, respectively [5].

PAI-1 - the main physiological inhibitor of t-PA belongs to the family of serpins; it inhibits activator with a high speed (the second order speed inhibition constant $-10^{7} \mathrm{M}^{-1} \cdot \mathrm{s}^{-1}$ ) [6]. Like other serpins, the inhibitor forms the equimolar complex with t-PA; the molecular mechanism of this interaction has been carefully studied [7]. PAI-1 interacts with polymeric fibrin and, being in fibrin-bound state, it can inhibit the clot lysis mediated by t-PA. The inhibitor belongs to the acute-phase proteins, its expression is increased by inflammation cytokines: interleukin- 6 (IL-6), tumor necrosis factor (TNF- $\alpha$ ), transforming growth factor $-\beta$ (TGF- $\beta$ ), as well as insulin an insulin-like growth factor (IGF-1), LDL [8].

The investigation of the role of t-PA i PAI-1 in pathological processes has shown that these proteins are the markers of development of thrombogenic or hemorrhagic complications. Thus, the decrease of the level of t-PA activity in blood was established under stenosis of coronary vessels, myocardial infarction, insult, while its increase was observed under oncological diseases, inflammation processes, hemorrhages [9, 10]. High concentration of PAI-1 in blood is revealed under deep vein thromboses, metabolic and hemolytic-uremic syndromes, and atherosclerosis [11]. The t-PA i PAI-1 activity is an important indicator of the functional state of fibrinolytic system; that is why, a necessity of determining these proteins causes no doubts. It should be noted that the home laboratory-clinical practice widely uses the tests which characterize the blood coagulation system, while the components of fibrinolytic system are not determined at all.
The work aim is to investigate the degree of oxidation modification of lipoproteins and the content of components of plasminogen activation system in the blood plasma of patients with stage II and resistant form of AHT as the prediction markers of complication development.

\section{Materials and Methods}

Investigations were carried out in blood plasma samples of patients of the SI NSC "Strazhesko Institute of Cardiology”, NAMS of Ukraine. As a result of diagnostic search the resistant form of AHT was confirmed in 25 patients. The resistant form of AHT was excluded in 30 patients after the prescribed standardized 3-component antihypertensive procedure, and they formed a group of patients with stage II AHT. The middle age of patients in the group of resistant hypertension and stage II AHT was $51.4 \pm 2.6$ and $45.3 \pm 3.7$, respectively. The disease duration in the group of patients with the stage II AHT and in the group of patients with resistant AHT was at an average $16.3 \pm 2.3$ and $13.4 \pm 2.0$ years. The control group consisted of 15 practically healthy persons of $49.2 \pm 2.1$ years. The algorithm of resistant AHT diagnostics corresponded to recommendations as to the therapy of arterial hypertension of the European Society of Hypertension and European Society of Cardiologists.

All the patients were subjected to complex clinical examination with allowance for the complaints, anamnestic and objective data. Instrumental examinations were used in all patients to assess the state of organs-targets.

Blood for the test was taken from the median cubital vein on an empty stomach. To obtain serum blood was taken into test-tubes, placed into thermostat for $30 \mathrm{~min}$ and centrifuged at $550 \mathrm{~g}$ for $20 \mathrm{~min}$. To obtain plasma blood was collected into the plastic tube which contained anticoagulant (3.8\% sodium citrate) in the ratio 9:1 and centrifuged at $400 \mathrm{~g}$ for $15 \min \left(4^{\circ} \mathrm{C}\right)$.

Glu-plasminogen was isolated from the citrate plasma of donor blood by the method of affine chromatography on lysine-sepharose in the presence of the inhibitor of proteinases - aprotynin (Contrical, Merkle GmbH and IDT Biologica, Germany) [12].

Fibrinogen was obtained from bull oxalate blood plasma by the method of fractional salting out by sodium sulphate [13].

DesAB fibrin was obtained from bull fibrinogen in the presence of sodium n-chloromercury ben- 
zoate - the inhibitor of factor XIIIa [14] and $0.1 \mathrm{M}$ 6 -aminohexane acid for removal of plasminogen additives.

Purity of the obtained protein preparations was controlled with the help of electrophoresis in PAAG [15].

Concentration of proteins in solutions was determined spectrophotometrically (SF-26, Russia) by the absorption value at 280 and $320 \mathrm{~nm}$. The corresponding coefficients of molar extinction $(1 \%, 1 \mathrm{~cm})$ and indices of molecular mass of the studied proteins $(\mathrm{kDa})$ were used for calculation of concentrations: Glu-plasminogen - 17.0 and 92, fibrinogen - 15.6 (pH 7.4) and 340, fibrin - $14.84(\mathrm{pH} 3.0)$ and 320; tissue activator of plasminogen - 20.0 and 70 .

To isolate euglobuline fraction $0.9 \mathrm{ml}$ of cooled distilled water and $0.1 \mathrm{ml}$ of $0.25 \%$ acetic acid were added to $0.1 \mathrm{ml}$ of plasma and incubated for $1 \mathrm{~h}$ at $4{ }^{\circ} \mathrm{C}$. After centrifugation during $10 \mathrm{~min}$ at $300 \mathrm{~g}$, the obtained precipitate was dissolved in $0.1 \mathrm{ml}$ of $0.05 \mathrm{M}$ tris- $\mathrm{HCl}$ buffer ( $\mathrm{pH} 7.4$ ) with $0.15 \mathrm{M} \mathrm{NaCl}$.

The activation activity of t-PA was determined in blood samples by the method described in [16].

The inhibitory activity of t-PA was determined in blood samples by the method described in [17].

The values of lipid metabolism indicators in the blood plasma, in particular, the content of general cholesterol (ChS), triglycerides (TG), ChS-LDL, ChS-HDL and fibrinogen were measured with the help of biochemical automatic analyzer "Biosystems A25” (Spain) with the use of the corresponding testsystems.

Arylesterase activity of paraoxonase-1 (PON-1, EC 3.1.1.2) was determined spectrophotometrically with the rate of phenylacetate transformtion into phenol at $270 \mathrm{~nm}$ [18].

Peroxidase activity of myeloperoxidase (MPO, EC 1.11.1.7) in the blood plasma was evaluated by the oxidation of chromogenic substrate 3.3'-dimetoxibenzidine (Acros organics, Belgium) $(3.8 \mathrm{mM})$. To exclude the possible effect on the result of other peroxidases the inhibitor MPO - hydrazide of 4-aminobenzoic acid (Acros organics, Belgium) $(50 \mu \mathrm{M})-$ was added to the plasma. The reaction was started by adding $\mathrm{H}_{2} \mathrm{O}_{2}$ in concentration of $100 \mu \mathrm{M}$, and the velocity of the decrease of optical density was recorded in kinetic regime during $68 \mathrm{~min}$ at $460 \mathrm{~nm}$ $\left(\Delta_{460} / \mathrm{min}\right)$ on SF-46 at $23{ }^{\circ} \mathrm{C}$ [19].

Activity of leucocyte elastase (EC 3.4.21.37) was determined spectrophotometrically by the rate of hydrolysis of N-tetra-butoxi-carbonyl-alanin- $p$ - nitrophenyl ether (BOC-Ala-ONp) (Sigma, USA) at $347 \mathrm{~nm}$ [20].

Superoxide dismutase activity (SOD, EC 1.15.1.1) was determined by the decrease of intensity of adrenaline autooxidation into adrenochrome [21].

The rate of spontaneous adrenalin oxidation was determined spectrofluorometrically $(510 \mathrm{~nm}$ emission, $410 \mathrm{~nm}$ excitation), adding to incubation medium (0.1 mM EDTA, $\left.0.05 \mathrm{M} \mathrm{Na}_{2} \mathrm{CO}_{3}\right) 1 \mathrm{mM}$ adrenalin solution (Sigma, USA) in $0.1 \mathrm{~N} \mathrm{HCl}$.

Catalase activity (EC 1.11.1.6) in the samples was determined using spectrophotometrical method by $\mathrm{H}_{2} \mathrm{O}_{2}$ ability to form a stable colored complex with molybdenum salts by the method of [22].

The content of products which react with thiobarbituric acid (TBA-RS) was determined spectrophotometrically by the method of [23].

The content of protein oxidation products in the blood serum and fractions HDL and LDL+VLDL (very low density lipoproteins) was determined spectrophotometrically by the method of [24].

Index of peroxide modification of atherogenic lipoproteins LDL+VLDL of blood serum was determined spectrophotometrically by the content of products of lipids peroxidation at $232 \mathrm{~nm}$ [25].

Statistical processing of the results was performed with the use of MSO Excel 2007 and a software package for microreader Ascent.

\section{Results and Discussion}

To characterize the state of fibrinolytic system the activity of t-PA and PAI-1 was determined in the blood plasma of patients with the stage II AHT and resistant form of AHT. It was done using quantitative methods for determining these indicators developed before [16, 17]. It should be emphasized that these methods allow us to reveal the level of just functionally active forms of these proteins, since under numerous diseases considerable quantities of structurally injured proteins are formed as a result of proteolytic and peroxide processes; activity of these proteins considerably differs from that in native forms, that is not taken into account under their identification by immunologic methods [26]. In accordance with the data of different authors the values of t-PA i PAI-1 activity vary essentially in blood plasma of healthy donors: 0.5-5 IU/ml and 11$15 \mathrm{IU} / \mathrm{ml}$, respectively [11, 27-29]. Such variability of results may be explained by individual features of the donors, as well as by differences in methodical approaches, which were used by the authors when determining activity of these indicators. 
The t-PA i PAI-1 level at normotension was estimated in the blood plasma samples of practically healthy persons. As is seen from Table 1, the average value of t-PA activity in these persons is at the lower limit of the norm, while that of PAI-1 exceeds the norm. The obtained results may be explained by the fact that synthesis of these proteins is disposed to circadian changes. The inhibitor concentration is maximum in the morning and decreases during a day, while the opposite day variations are characteristic of the activator [6].

Concentration of fibrinogen which is the basic component of the system of coagulation and protein of the acute phase in the blood plasma of both conventionally healthy persons and patients with stage II AHT and resistant AHT meets the norm. At the same time activity of proteins of the plasminogen activation system essentially changes - in the both groups of patients the content of PAI- 1 increases on the background of a decrease of t-PA content. Thus the activator level in the plasma of patients with stage II AHT decreases twice compared with the group of practically healthy persons, while at the resistant form of the disease proceeding it decreases more than 2.5 times. Therewith the inhibitor activity increases 1.5 times in patients with stage II AHT and 2 times in patients with the resistant form of AHT. Thus, a decrease of fibrinolytic potential is found in the patients with arterial hypertension of different proceeding.

An unbalance between the level of plasminogen activator and its inhibitor, which are synthesized and released to the blood flow by endotheliocytes, points to perturbation of regulation mechanisms of endothelial fibrinolysis that may be a cause of development of thrombogenic complications. In accordance with the data obtained a more potent inhibition of t-PA activity is observed at the resistant form of the disease proceeding that evidences for development of endothelial dysfunction in the patients of this group.

Quantitative characteristics of lipoproteins, and, first of all $\mathrm{ChS}$ content in them, are usually taken into account when estimating the state of lipid metabolism in patients with AHT. These indices are used in clinical practice to estimate the efficiency of therapy. In accordance with modern ideas the qualitative characteristic of lipoproteins, their properties are determined by protein molecules - apoproteins and enzymes, activity of the latter is of a higher importance, compared with the level of lipoproteins in the blood flow or ChS content in them [30, 31]. PON-1 occupies an important place among enzymes associated with lipoproteins; it determines antioxidant, antiinflammation, antithrombotic and antiatherogenic properties of HDL [18, 32]. MPO, also associated with lipoproteins, is released from activated polymorphous-nuclear leucocytes in the process of activation of inflammation reaction and can cause oxidative modification of lipoproteins and other macromolecules, inactivation of PON-1 promoting atherogenesis [33, 34]. Indices of lipid metabolism in patients with stage II AHT and in patients with resistant AHT are presented in Table 2. As it is seen, only the level of ChS LDL and ChS VLDL significantly increased in stage II AHT and resistant AHT patients.

The conducted investigations have shown that a tendency to the decrease of arylesterase activity of PON-1 is observed in the patients with stage II AHT compared with practically healthy persons (Table 3). At the same time, arylesterase activity of PON-1 in patients with resistant AHT decreases reliably by $60 \%$ compared with the group of practically healthy persons and by 55\% compared with the group of patients with stage II AHT. PON-1, when hydrolyzing lipid peroxides, favors elimination of oxidized LDL, inhibition of ChS biosynthesis and stimulation

Ta b le 1. Content of fibrinogen, $t-P A$ and PAI-1 in blood plasma of patients with stage II AHT and resistant form of $A H T(M \pm m)$

\begin{tabular}{l|c|c|c}
\hline \multicolumn{1}{c|}{ Indices } & $\begin{array}{c}\text { Practically healthy } \\
\text { persons, } n=15\end{array}$ & $\begin{array}{c}\text { Patients with stage II } \\
\text { AHT, } n=30\end{array}$ & $\begin{array}{c}\text { Patients with resistant } \\
\text { form of AHT, } n=25\end{array}$ \\
\hline Fibrinogen, g/l & $2.83 \pm 0.12$ & $2.50 \pm 0.11$ & $2.74 \pm 0.23$ \\
Activity PAI-1, MO/ml & $21.86 \pm 3.36$ & $34.91 \pm 3.86^{*}$ & $46.27 \pm 2.10^{*}$, \\
Activity t-PA, MO/ml & $0.50 \pm 0.13$ & $0.25 \pm 0.07^{*}$ & $0.19 \pm 0.07^{*}$ \\
\hline
\end{tabular}

$P<0.05$. *Changes are trustworthy compared with a group of practically healthy persons; ${ }^{*}$ changes are trustworthy compared with a group of patients with stage II AHT 
of HDL-mediated ChS efflux from macrophages, it also prevents accumulation of ChS and oxysterols in cells. Besides, PON-1 protects HDL themselves from the excessive lipid peroxidation [18, 32].

The arylesterase activity of PON-1 decreases on the background of the increase in the content of products of lipid peroxidation, in particular, TBA-RS in the blood serum by $10 \%$ and $18 \%$, respectively, in patients with the stage II AHT and resistant AHT compared with the group of practically healthy persons (Table 4).

At the same time a more expressed activation of the processes of free-radical oxidation of protein molecules is observed in patients that is evidenced by the increase of carbonyl products of free-radical oxidation of proteins in the blood serum by $36 \%$ and $49 \%$, respectively, in patients with stage II AHT and resistant form of AHT. The increase of the content of these products in lipoproteide fractions in patients with stage II AHT and resistant form of AHT also attracts attention: it increases, respectively, by 51 and $77 \%$ in LDL+VLDL fraction and by 48 and $98 \%$ in HDL fraction (Table 4). There is the increase of the index of peroxide modification of atherogenic lipoproteins (LDL+VLDL) in patients with stage II AHT and resistant form of AHT that is estimated by the content of products of free-radical peroxidation of lipids in this fraction (Table 4) as 33 and 54\%, respectively, compared with the group of practically healthy persons. The obtained results may evidence for peroxidized state of lipoprotein components and can become the basis of high atherogenic blood potential. The indicated changes proceed against a background of a decrease of activity of the enzyme link of antioxidant defense system (Table 3). Thus, activity of superoxide dismutase in blood serum of the both groups of patients decreases by $24 \%$, activi- ty of catalase - by 35 and 26\%, respectively in the patients with stage II AHT and resistant AHT compared with the group of practically healthy persons. The found changes reflected the general response of patient's organisms and pointed to formation of oxidative stress under the participation of both lipid and protein components, and inhibition of mechanisms of antioxidant defense, directed to the decrease of the level of active oxygen forms and products of free-radical oxidation of macromolecules.

The increase of myeloperoxidase activity by 58 and $121 \%$, respectively, is observed in the examined patients with the stage II AHT and resistant AHT, compared with the group of practically healthy persons (Table 3). Today, there is a lot of evidences of the significant part of leucocytes in the process of vessels injury. It is supposed, in particular, that activation of leucocytes can serve as an alternative risk factor in development of atherosclerosis. Myeloperoxidase is contained in azurophile granules of neutrophiles and is released to the extracellular space under activation of these cells. The displayed increase of myeloperoxidase activity in the examined patients indicates stimulation and maintenance of functional activity of leucocytes and availability of inflammation reaction, especially in the patients with resistant form of AHT. Myeloperoxidase forms a complex with HDL-associated enzyme PON-1 in blood circulation. PON-1 inhibits partially myeloperoxidase activity, while the latter is able to inactivate PON-1, oxidizing tyrosine-71 residue that results in the infringement of the link of the enzyme molecule with HDL. A number of active forms of oxygen are formed as a result of myeloperoxidase activation that can lead to the damage of macromolecules, lipoproteins. A local aggravation of vessel inflammation is possible in the case of myeloperoxidase binding

Ta b le 2. Indices of lipid metabolism in patients with the stage II AHT and resistant form of AHT (M $\pm m)$

\begin{tabular}{l|c|c|c}
\hline \multicolumn{1}{c|}{ Indices } & $\begin{array}{c}\text { Practically healthy } \\
\text { persons, } n=15\end{array}$ & $\begin{array}{c}\text { Patients with stage II } \\
\text { AHT, } n=30\end{array}$ & $\begin{array}{c}\text { Patients with resistant } \\
\text { form of AHT, } n=25\end{array}$ \\
\hline $\mathrm{ChS}, \mu \mathrm{mol} / 1$ & $4.95 \pm 0.27$ & $5.36 \pm 0.32$ & $5.13 \pm 0.16$ \\
$\mathrm{TG}, \mu \mathrm{mol} / 1$ & $1.38 \pm 0.21$ & $1.93 \pm 0.28$ & $1.62 \pm 0.13$ \\
$\mathrm{ChS} \mathrm{HDL}, \mu \mathrm{mol} / 1$ & $1.24 \pm 0.05$ & $1.29 \pm 0.05$ & $1.26 \pm 0.04$ \\
$\mathrm{ChS} \mathrm{LDL}, \mu \mathrm{mol} / 1$ & $2,30 \pm 0.19$ & $3.14 \pm 0,19^{*}$ & $3.52 \pm 0.11^{*}$ \\
$\mathrm{ChS} \mathrm{VLDL}, \mu \mathrm{mol} / 1$ & $0.28 \pm 0.04$ & $0.64 \pm 0.12^{*}$ & $0.70 \pm 0.06^{*}$ \\
Coefficient of atherogenicity & $2.99 \pm 0.12$ & $3.16 \pm 0.22$ & $2.95 \pm 0.15$ \\
\hline
\end{tabular}

$P<0.05$, *changes are reliable compared with the group of practically healthy persons; ${ }^{*}$ changes are reliable compared with the group of patients with stage II AHT 
Table 3. Activity of PON-1, catalase, SOD, MPO, leucocyte elastase in blood of patients with AHT of stage II and resistant form of AHT $(M \pm m)$

\begin{tabular}{l|c|c|c}
\hline \multicolumn{1}{c|}{ Indices } & $\begin{array}{c}\text { Practically healthy } \\
\text { persons, } n=15\end{array}$ & $\begin{array}{c}\text { Patients with stage II } \\
\text { AHT, } n=30\end{array}$ & $\begin{array}{c}\text { Patients with resistant } \\
\text { form of AHT, } n=25\end{array}$ \\
\hline PON-1 activity, $\mathrm{kU} / \mathrm{l}$ & $4.26 \pm 0.83$ & $3.73 \pm 0.48$ & $1.69 \pm 0.58^{*} \#$ \\
Catalase activity, un./l & $7.89 \pm 0.42$ & $5.10 \pm 0.36^{*}$ & $5.78 \pm 0.56^{*}$ \\
SOD activity, un./ & $1990 \pm 137$ & $1519 \pm 126^{*}$ & $1507 \pm 120^{*}$ \\
MPO activity, $\Delta \mathrm{E}_{460} / \mathrm{min}$ & $0.0024 \pm 0.0005$ & $0.0038 \pm 0.0009^{*}$ & $0.0053 \pm 0.0012^{*}$ \\
$\begin{array}{l}\text { Leucocyte elastase } \\
\text { activity, } \mathrm{nmol} / \mathrm{ml} \cdot \mathrm{min}\end{array}$ & $0.395 \pm 0.026$ & $0.293 \pm 0.024^{*}$ & $0.273 \pm 0.048^{*}$ \\
\hline
\end{tabular}

$\overline{P<0.05}$, *changes are reliable compared with a group of practically healthy persons; ${ }^{*}$ changes are reliable compared with a group of patients with stage II AHT

Table 4. Content of products of free-radical oxidation of proteins and lipids in blood of patients with stage II AHT and resistant form of AHT $(M \pm m)$

\begin{tabular}{|c|c|c|c|}
\hline Indices & $\begin{array}{l}\text { Practically healthy } \\
\text { persons, } n=15\end{array}$ & $\begin{array}{c}\text { Patients } \\
\text { with stage II } \\
\text { AHT, } n=30\end{array}$ & $\begin{array}{l}\text { Patients with resistant } \\
\text { form of AHT, } n=25\end{array}$ \\
\hline Content of TBA-RS, conv. un./l & $9.77 \pm 0.21$ & $10.79 \pm 0.13^{*}$ & $11.58 \pm 0.11^{*, \#}$ \\
\hline $\begin{array}{l}\text { Products of free-radical oxidation of } \\
\text { proteins in blood serum, conv. un./ml }\end{array}$ & $4.13 \pm 0.16$ & $5.62 \pm 0.18^{*}$ & $6.17 \pm 0.11^{*, \#}$ \\
\hline $\begin{array}{l}\text { Products of free-radical oxidation of } \\
\text { proteins in LDL+VLDL, conv. un./ml }\end{array}$ & $0.57 \pm 0.05$ & $0.86 \pm 0.05^{*}$ & $1.01 \pm 0.05^{*, \#}$ \\
\hline $\begin{array}{l}\text { Products of free-radical oxidation } \\
\text { of proteins in HDL, conv. un./ml }\end{array}$ & $1.94 \pm 0.09$ & $2.88 \pm 0.21^{*}$ & $3.84 \pm 0.26^{*, \#}$ \\
\hline $\begin{array}{l}\text { Index of peroxide modification } \\
\text { of atherogenic lipoproteins } \\
\text { (LDL+VLDL), conv. un./mg of lipids }\end{array}$ & $2.41 \pm 0.10$ & $3.21 \pm 0.13^{*}$ & $3.72 \pm 0.16^{*, \#}$ \\
\hline
\end{tabular}

to endothelium and its activation. It has been demonstrated in a number of works that the increase of the value of the ratio MPO/PON-1 may be used as a predictor of development of the acute coronary syndrome - the event that can develop as a result of the progress of cardiovascular pathology and threaten the patient's life [33, 34]. Almost a 2-fold increase of the ratio MPO/PON-1 in the patients with stage II AHT and 5.6-fold increase in the patients with resistant AHT was established in our research as compared with the group of practically healthy persons that increases a risk of development of an acute coronary syndrome in such patients. A long-term increase of PAI-1 content can inhibit the process of angiogenesis and favor development of fibrosis that can also create conditions for development of complications of cardiovascular diseases [35].

At the same time it should be noted that in spite of the fact that quantitative indices of lipid metabolism (Table 2) of the patients with stage II AHT and resistant AHT do not practically differ from those in the group of practically healthy persons (except for ChS-LDL and ChS-VLDL), activation of free-radical oxidative reactions is observed in these patients, that is indicated by reliably high, compared with control, equal products of peroxidation of lipids and proteins in the blood serum. Catalase and superoxide dismutase activity remains considerably below the control level that indicates the presence of unbalance between pro- and antioxidative systems. Attention is 
attracted by the (reliably higher than control) value of the index of peroxide modification of lipoproteins in atherogenic fractions (LDL and VLDL) because of accumulation of products of lipids and proteins peroxidation in them. Analogous qualitative changes also take place in HDL. That may be determined by the inhibition of activity of PON-1 which is responsible for the defense of HDL from the effect of active oxygen forms and by simultaneous increase of myeloperoxidase activity directed to peroxidation of lipoproteins and other macromolecules taking part in atherogenesis processes and progress of pathological process under atherogenesis. Proteolytic enzymes play a significant part in development of atherosclerotic process. Leucocytic elastase is the most active enzyme taking part in the injury of intercellular matrix under development of inflammation and local pathologic processes. Human leucocyte elastase is the basic proteinase of azurofile granules of polymorphonuclear leucocytes and causes the highest destructive effect on biological structures. Almost all the components of extracellular matrix are potential substrates of elastase. These are extracellular matrix proteins - collagen, elastin, fibrin, fibronectin, complement receptors, immunoglobulins, as well as cytokins (IL-1, IL-2, IL-6, TNF- $\alpha$ ); hydrolyzing them, this enzyme appears as the inflammation regulator [36]. The 26-30\% decrease of leucocytic elastase activity in the blood serum of examined patients of the both groups was established as a result of conducted studies. The decrease of activity of leucocitic elastase in patients with stage II AHT agrees with the data of other authors and may be determined by the exhaustion of possibilities of its release and/or synthesis, allowing for its significant role in formation of the pathologic process at the stage of prehypertension.

We should also emphasize a possible role of enzymes of myeloperoxidase and leucocytic elastase in destabilization of atherosclerotic plaque. As is known, thinning-out and break of fibrous plaques is the key link of this process which may occur as a result of proteinase activation under the effect of hypochlorite formed during activation of myeloperoxidase. Activation of myeloperoxidase evidences for high cytotoxicity of polymorphous-nuclear leucocytes. These changes jointly with a decrease in activity of PON-1 and antioxidant defense enzyme (catalase and superoxide dismutase) can favor the maintenance of high level oxidation of lipoproteins. The oxidized lipoproteins, in their turn, are able to intensify the adhesion of blood cells to endothelium, to induce expression of growth factors in the smooth-muscle cells, to inhibit expression of NOsynthase and to cause the dysfunction of endothelium [37, 38].

Vascular endothelium plays the important role in regulation of fibrinolysis. In particular, this is displayed in regulation of production of t-PA and PAI-1. The dysfunction of endothelium, taking place in patients with AHT, is the early important mechanism of the progress of atherosclerotic process. In particular, it is caused by development of oxidative stress and accessibility decrease of NO which is also included to antithrombotic properties of endothelium surface, partially through the inhibition of adhesion and aggregation of thrombocytes. Besides, NO takes part in regulation of t-PA release. Oxidized HDL interact with specific receptors, in particular, LOX-1 (they do not react with them in norm); through activation of signal paths these HDL lead to inhibition of eNOS (nitrogen oxide endothelial synthase) activity and formation of NO. The increase of PAI-1 content and inhibition of eNOS can result in the development to fibrosis of the vessels, heart and kidneys that, in its turn, will favor the progress of arterial hypertension.

The presented results evidence for clinical significance of the complex analysis of the degree of oxidative modification of lipoproteins and content of components of the plasminogen activation system for estimation of therapy efficiency of AHT of various proceeding and for prophylaxis of vascular complications. 
ВИЗНАЧЕННЯ ВМІСТУ

КОМПОНЕНТІВ ПЛАЗМІНОГЕН/

ПЛАЗМІНОВОЇ СИСТЕМИ

ТА ПОКАЗНИКІВ ОКИСНОЇ МОДИФІКАЦЇ̈ ЛІПОПРОТЕЇНІВ ЗА АРТЕРІАЛЬНОЇ ГІПЕРТЕНЗІЇ

О. І. Юсова ${ }^{1}$ О. В. Савчук 1 , Т. В. Гриненко,

О. Б. Кучменко ${ }^{2}$ Л. С. Мхітарян ${ }^{2}$,

О. Г. Купчинська ${ }^{2}$, I. Н. Свстратова ${ }^{2}$,

О. О. Матова ${ }^{2}$, Н. М. Василинчук ${ }^{2}$,

T. Ф. Дроботько ${ }^{2}$

${ }^{1}$ Інститут біохімії ім. О. В. Палладіна НАН України, Київ;

e-mail: yusova07@gmail.com;

${ }^{2} Д У$ ННЦ «Інститут кардіології ім. академіка

М. Д. Стражеска» НАМН України, Київ

Досліджували показники окисної модифікації ліпопротеїнів і вміст компонентів плазміноген/плазмінової системи - тканинного активатора (t-PA) i інгібітора активаторів плазміногену-1 (PAI-1) у пацієнтів із артеріальною гіпертензією II ступеня (АГ) і резистентну АГ. Встановили, що рівень t-РА в плазмі крові пацієнтів нижче норми в 2 рази за АГ II ступеня і в 2,5 за резистентної АГ, активність інгібітора вище в 1,5 і 2,0 рази відповідно. Показано, що у хворих із АГ різного перебігу зниження фібринолітичного потенціалу може бути причиною розвитку тромбогенних ускладнень. Пригнічення активності t-PA в хворих iз резистентною АГ свідчить про розвиток ендотеліальної дисфункції. Також встановлено вірогідне накопичення продуктів окислення ліпідів і протеїнів, зниження активності антиоксидантних ензимів (супероксиддисмутази, каталази) та зміни активності ензимів, що асоційовані з ліпопротеїнами високої щільності (зниження активності параоксонази-1, зростання активності мієлопероксидази). Показники продуктів окислення ліпопротеїни, зміни активності t-PA i PAI-1 можуть слугувати прогностичними маркерами розвитку судинних ускладнень та для оцінки ефективності терапії в пацієнтів з АГ.

К л ю ч о в і с ло в а: окислені ліпопротеїни, тканинний активатор плазміногену, інгібітор активатора плазміногену-1, артеріальна гіпертензія.
ОПРЕДЕЛЕНИЕ СОДЕРЖАНИЯ КОМПОНЕНТОВ ПЛАЗМИНОГЕН/ ПЛАЗМИНОВОЙ СИСТЕМЫ И ПОКАЗАТЕЛЕЙ ОКИСЛИТЕЛЬНОЙ МОДИФИКАЦИИ ЛИПОПРОТЕИНОВ ПРИ АРТЕРИАЛЬНОЙ ГИПЕРТЕНЗИИ

Е. И. Юсова ${ }^{1}$ О. В. Савчук 1 Т. В. Гриненко, Е. Б. Кучменко ${ }^{2}$ Л. С. Мхитарян ${ }^{2}$,

Е. Г. Купчинская ${ }^{2}$, И. Н. Евстратова ${ }^{2}$,

Е. А. Матова ${ }^{2}$, Н. Н. Василинчук ${ }^{2}$, T. Ф. Дроботько ${ }^{2}$

${ }^{1}$ Институт биохимии им. А. В. Палладина НАН Украины, Киев; e-mail: yusova07@gmail.com;

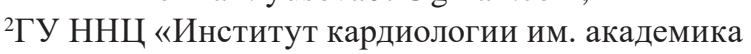

Н. Д. Стражеско» НАМН Украины, Киев

Исследовали показатели окисной модификации липопротеинов и содержание компонентов плазминоген/плазминовой системы - тканевого активатора (t-PA) и ингибитора активаторов плазминогена-1 (PAI-1) у пациентов с артериальной гипертензией II степени (АГ) и резистентной АГ. Установили, что уровень t-РА в плазме пациентов ниже нормы в 2 раза при АГ II степени и в 2,5 при резистентной АГ, активность ингибитора выше в 1,5 и 2,0 раза соответственно. Показано, что у пациентов с АГ разного протекания снижение фибринолитического потенциала может быть причиной развития тромбогенных осложнений. Угнетение активности t-PA у больных с резистентной АГ свидетельствует о развитии эндотелиальной дисфункции. Также установлено достоверное накопление продуктов окисления липидов и протеинов, снижение активности антиоксидантных энзимов (супероксиддисмутазы, каталазы) и изменения активности ассоциированных с липопротеинами высокой плотности энзимов (снижение активности параоксоназы-1 и увеличение активности миелопероксидазы). Показатели продуктов окисления липопротеинов, изменение активности t-PA и PAI-1 могут служить прогностическими маркерами развития осложнений и для оценки эффективности терапии у пациентов с АГ.

Ключевы е слова: окисленные липопротеины, тканевой активатор плазминогена, ингибитор активатора плазминогена-1, артериальная гипертензия. 


\section{References}

1. Dinh QN, Drummond GR, Sobey CG, Chrissobolis S. Roles of inflammation, oxidative stress, and vascular dysfunction in hypertension. Biomed Res Int. 2014; 2014: 406960.

2. Solak Y, Afsar B, Vaziri ND, Aslan G, Yalcin CE, Covic A, Kanbay M. Hypertension as an autoimmune and inflammatory disease. Hypertens Res. 2016; 39(8): 567-573.

3. van der Stoep M, Korporaal SJ, Van Eck M. High-density lipoprotein as a modulator of platelet and coagulation responses. Cardiovasc Res. 2014; 103(3): 362-371.

4. Kolev K, Longstaff $\mathrm{C}$. Bleeding related to disturbed fibrinolysis. Br J Haematol. 2016; 175(1): 12-23.

5. Hoylaerts M, Rijken DC, Lijnen HR, Collen D. Kinetics of the activation of plasminogen by human tissue plasminogen activator. Role of fibrin. J Biol Chem. 1982; 257(6): 2912-2919.

6. Lijnen HR. Pleiotropic functions of plasminogen activator inhibitor-1. J Thromb Haemost. 2005; 3(1): 35-45.

7. Reilly CF, Hutzelmann JE. Plasminogen activator inhibitor-1 binds to fibrin and inhibits tissue-type plasminogen activator-mediated fibrin dissolution. J Biol Chem. 1992; 267(24): 17128-17135.

8. Brown NJ. Therapeutic potential of plasminogen activator inhibitor-1 inhibitors. Ther Adv Cardiovasc Dis. 2010; 4(5): 315-324.

9. Meade TW, Howarth DJ, Cooper J, MacCallum PK, Stirling Y. Fibrinolytic activity and arterial disease. Lancet. 1994; 343(8910): 1442.

10. Wojtukiewicz MZ, Sierko E, Klement P, Rak J. The hemostatic system and angiogenesis in malignancy. Neoplasia. 2001; 3(5): 371-384.

11. Zorio E, Gilabert-Estellés J, España F, Ramón LA, Cosín R, Estellés A. Fibrinolysis: the key to new pathogenetic mechanisms. Curr Med Chem. 2008; 15(9): 923-929.

12. Deutsch DG, MertzET. Plasminogen: purification from human plasma by affinity chromatography. Science. 1970 Dec 4;170(3962):1095-6.

13. Varetskaya TV, Loseva AL, Yatsenko VI. On the determination of thrombin activity. Ukr Biokhim Zhurn. 1961; 33(5): 657-666. (In Ukrainian).

14. Pozdnjakova TM, Musjalkovskaja AA, Ugarova TP, Protvin DD, Kotsjuruba VN. On the properties of fibrin monomer prepared from fibrin clot with acetic acid. Thromb Res. 1979; 16(1-2): 283-238.

15. Laemmli UK. Cleavage of structural proteins during the assembly of the head of bacteriophage T4. Nature. 1970; 227(5259): 680-685.

16. Kondratiuk AS, Yusova OI, Grynenko TV. Identification of activity of tissue plasminogen activator in blood plasma. Lab Diagnostics. 2011; 3(57): 3-9. (In Ukrainian).

17. Roka-Moya YM, Zhernossekov DD, Kondratyuk AS, Grinenko TV. Development and optimization of the methods for determining activity of plasminogen activator inhibitor-1 in plasma. Ukr Biokhim Zhurn. 2013; 85(4): 111118. (In Ukrainian).

18. Manolescu BN, Berteanu M, Cintezã D. Effect of the nutritional supplement ALAnerv ${ }^{\circledR}$ on the serum PON1 activity in post-acute stroke patients. Pharmacol Rep. 2013; 65(3): 743-750.

19. Gorudko IV, Cherkalina OS, Sokolov AV, Pulina MO, Zakharova ET, Vasil'ev VB, Cherenkevich SN, Panasenko OM. New approaches to the measurement of the concentration and peroxidase activity of myeloperoxidase in human blood plasma. Bioorg Khim. 2009; 35(5): 629-639. (In Russian).

20. Kubyshkin AV, Fomochkina II. Elastolytic activity of bronchoalveolar lavage fluid in acute lung inflammatory injury. Ukr Biokhim Zhurn. 2008; 80(1): 89-95. (In Russian).

21. Misra HP, Fridovich I. The role of superoxide anion in the autoxidation of epinephrine and a simple assay for superoxide dismutase. $J$ Biol Chem. 1972; 247(10): 3170-3175.

22. Koroliuk MA, Ivanova LI, Mayorova IG, Tokarev VE. A method of determining catalase activity. Lab Delo. 1988; (1): 16-19. (In Russian).

23. Stalnaya ID, Garishvili TG. Method of determination of malonic dialdehyde with tiobarbituric acid. In the book "Modern methods in biochemistry"/ Ed. V.N. Orekhovich. Moscow: Medicine, 1977. 375 p. (In Russian).

24. Dubinina EE, Burmistrov SO, Khodov DA, Porotov IG. Oxidative modification of human serum proteins. A method of determining it. Vopr Med Khim. 1995; 41(1): 24-26. (In Russian).

25. Patent 30972A UA 6G 01 N33/48 Method of diagnosis of progressive atherosclerosis / Ievstratova IN, Mkhitaryan LS, Orlova NM, Kasimirko EI, Fedun NM, Drobotko TF. 
Published on 15.12.2000, Bull. N 7. (In Ukrainian).

26. Klys' YG, Zajtseva NV, Kizim AI, Verevka SV. Proteolytic derivatives of plasminogen as a factor in malignancy development. Oncology. 2010; 12(1): 17-21. (In Russian).

27. Chapman MP, Moore EE, Moore HB, Gonzalez E, Gamboni F, Chandler JG, Mitra S, Ghasabyan A, Chin TL, Sauaia A, Banerjee A, Silliman CC. Overwhelming tPA release, not PAI-1 degradation, is responsible for hyperfibrinolysis in severely injured trauma patients. J Trauma Acute Care Surg. 2016; 80(1): 16-25.

28. Al-Hamodi Z, Ismail IS, Saif-Ali R, Ahmed KA, Muniandy S. Association of plasminogen activator inhibitor-1 and tissue plasminogen activator with type 2 diabetes and metabolic syndrome in Malaysian subjects. Cardiovasc Diabetol. 2011; 10: 23.

29. Wiman B, Andersson T, Hallqvist J, Reuterwall C, Ahlbom A, deFaire U. Plasma levels of tissue plasminogen activator/plasminogen activator inhibitor-1 complex and von Willebrand factor are significant risk markers for recurrent myocardial infarction in the Stockholm Heart Epidemiology Program (SHEEP) study. Arterioscler Thromb Vasc Biol. 2000; 20(8): 2019-2023.

30. Mangge H. Beyond Cholesterol - New Cardiovascular Biomarkers. Nestle Nutr Inst Workshop Ser. 2016; 84: 81-88.

31. Ramirez A, Hu PP. Low high-density lipoprotein and risk of myocardial infarction. Clin Med Insights Cardiol. 2015; 9: 113-117.

32. Kovalenko VM, Kuchmenko OB, Mkhytarian LS. Molecular and genetic peculiarities of the paraoxonase functioning and importance in the development of cardiovascular pathology. Ukr Cardiol J. 2014; (5): 105-116. (In Ukrainian).

33. Huang $\mathrm{Y}, \mathrm{Wu} \mathrm{Z}$, Riwanto $\mathrm{M}$, Gao $\mathrm{S}$, Levison $\mathrm{BS}, \mathrm{Gu} \mathrm{X}, \mathrm{Fu} \mathrm{X}$, Wagner MA, Besler C, Gerstenecker G, Zhang R, Li XM, DiDonato AJ, Gogonea V, Tang WH, Smith JD, Plow EF, Fox PL, Shih DM, Lusis AJ, Fisher EA, DiDonato JA, Landmesser U, Hazen SL. Myeloperoxidase, paraoxonase-1, and HDL form a functional ternary complex. J Clin Invest. 2013; 123(9): 3815-3828.

34. Loria V, Dato I, Graziani F, Biasucci LM. Myeloperoxidase: a new biomarker of inflammation in ischemic heart disease and acute coronary syndromes. Mediators Inflamm. 2008; 2008: 135625.

35. D'Elia JA, Bayliss G, Gleason RE, Weinrauch LA. Cardiovascular-renal complications and the possible role of plasminogen activator inhibitor: a review. Clin Kidney J. 2016; 9(5): 705-712.

36. Olempieva EV. Changes of components of extracellular matrix at hypertonic disease in pregnant and nonpregnant women. Terra Medica. 2013; (4): 16-19. (In Russian).

37. Carbone F, Mach F, Montecucco F. Update on the role of neutrophils in atherosclerotic plaque vulnerability. Curr Drug Targets. 2015; 16(4): 321-333.

38. de Vries MA, Alipour A, Birnie E, Westzaan A, van Santen S, van der Zwan E, Liem AH, van der Meulen N, Cabezas MC. Coronary leukocyte activation in relation to progression of coronary artery disease. Front Med. 2016; 10(1): 85-90.

Received 30.11.2017 